
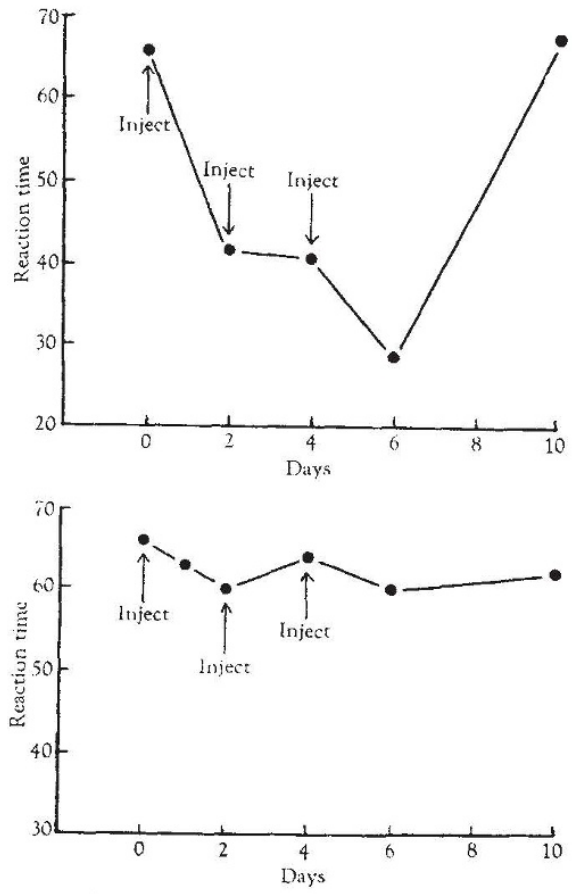

Fig. 4. Changes in the reaction time following two series of T.A.B. Upper, first series of injections; lower, second series of injections

ation, but the bulk of the evidence so far strongly implicates the involvement of the intracellular electron transfer systems and hence supports the views of Tahmisian ${ }^{7}$ and many others that these systems are of paramount importance in the reaction of a tissue to radiation.

Department of Anatomy,

W. K. Metcale

University of Bristol.

${ }^{1}$ Metcalf, W. K., Phys. in Med. and Biol., 6, $42 \tau$ (1962).

Metealf, W. K., Phys. in Med, and Biol., 6, 437 (1962).

Metcalf, w. K., J. Anat., 97, 144 (P) (1962).

"Metcalf, W. K., Nature, 194, 783 (1962).

"Dubois, K. P., and Petersen, D. F., Amei. .I. Physiol., 176, 282 (1954). "Bekkum, D. W. van, CIBA Found. Symp. on Ionizing Radiations and

; Tahmisian, T. N., Peaceful Eses of Atomic Energy, 11, 256 (1956).

\section{Binding of Strontium in Blood}

WE have reported ${ }^{1}$ that, following the ingestion of radioactive strontium by normal subjects, the specific activity in urine was appreciably greater than that in contemporary plasma. Consequently, wo postulated that strontium existed in blood in two different chemical forms. We were unable, however, to find any difference in the specific activity of strontium in plasma ultrafiltrate compared with that of the non-dialysable fraction. This result prompted further experiments which have now revealed an artefact in the original measurements. Heparin, which is known to be a source of adventitious stable strontium ${ }^{2}$, was used in the collection of the blood. An incorrect allowance for this gave us falsely low values for the specific activity of plasma. A complete re-estimation of the relative specific activities of strontium in urine and plasma has therefore been made. The results of theso measurements are given in Table 1 . The prob-

Table 1. Spechic ACtivity of Strontium in Urine and Prasma Subject Specifle activity of st
(counts $/ \mathrm{min} / \mu \mathrm{g})$
Urime

R. H. M.
G. E. H.
A. J. P.

P. W. F. C.

176
208
135
240

222

\section{Ratio} specifie activity urine/plasmit

1.03
1.43

$1 \cdot 43$
0.85

$1 \cdot 25$

$1 \cdot 1 \pm 0 \cdot 1$

ability of the ratio being greater than unity is 32 per cont, the 95 per cent confidence limits 0.84 and 1.40 .

In some experiments already reported ${ }^{1}$, and in others unreported, heparin (batch No. 64373) was added to the blood samples. This addition was $40 \mathrm{mg}$ (equivalent to 4,800 units) to all blood samplos of $100 \mathrm{ml}$. or more. As the strontium content of this amount of heparin is known, it was possible to correct these earlier determina, tions. The observed and corrected values for the specific activity of strontium in urine relative to that in plasma are given in Table 2. The mean corrected value of tho ratio $0.98 \pm 0.05$ confirms the more recent values in Table 1.

Table 2. EFFect OF HEPARIN ON THE OBSERVED Ratio OF SPBCLF Actrvity of StrontiuM IN URINe Relative TO PLasma

\begin{tabular}{|c|c|c|}
\hline \multirow{2}{*}{ Subject } & \multicolumn{2}{|c|}{$\begin{array}{l}\text { Specific activity of strontium in ur } \\
\text { relative to plasma }\end{array}$} \\
\hline & Observed & $\begin{array}{l}\text { plasma } \\
\text { Corrected }\end{array}$ \\
\hline A. J. P. & $2 \cdot 68$ & $1 \cdot 38$ \\
\hline P. W. E. & 1.70 & 0.67 \\
\hline & $1 \cdot 18$ & 0.98 \\
\hline R. H. M. & $1 \cdot 70$ & 0.81 \\
\hline ", & $1 \cdot 69$ & 0.85 \\
\hline ," & 1.80 & $1 \cdot 10$ \\
\hline ,", & $1 \cdot 17$ & $1 \cdot 02$ \\
\hline$"$, & 1.01 & 0.80 \\
\hline$\therefore$ & 1.45 & $1 \cdot 14$ \\
\hline $\mathrm{F}$ & $1 \cdot 49$ & 1.02 \\
\hline F. S. W. & $2 \cdot 20$ & 1.23 \\
\hline & Mean & $0.98 \pm 0.05$ \\
\hline
\end{tabular}

We conclude that the specific activities of strontiun in plasma and urine are probably equal. It should be added that the same result has also been obtained for calcium by others ${ }^{3,4}$. There is, therefore, no experimental evidence to support the view that there are two different forms of strontium (or calcium) in blood which the kidney is able to differentiate.

T. E. F. CARR

G. E. Harrison

J. F. LoutiT

Medical Research Council,

Alice Sutton

Radiobiological Research Unit, Harwell, Berks.

${ }^{1}$ Carr, 'T. E. F., Harrison, G. E., Loutit, J. F., and Sutton, Alice, Nature, 195, $913(1962)$. 2 Harrison, G. E., Raymond, W. H. A., and Thretheway, H. C., Clin. Sci.,
14, 681 (1955).

${ }^{3}$ Nordin, B. F. C. (personal eommunication). + Blau, M., Spencer, H., Swernov, J., and Laszlo, D. Science, 120, 10:99
(1954).

\section{A Multicomponent X-ray Survival Curve for Mouse Lymphosarcoma Cells irradiated in vivo}

NEARLY all investigations hitherto reported of the survival of animal cell populations exposed to single doses of ionizing radiations have yielded data which have been fitted by curves of the same general shape: a shoulder of varying size (which may be absent) followed by a region of exponential decrease. Only a single exponential component has been found even in those investigations in which survival was studied to fairly low lovels (less than $\left.10^{-3}\right)$, irrespective of whether survival was measured by colony formation in vitro ${ }^{1-5}$, or in vivo by tumour induction $^{6,7}$. These results have been obtained despite the fact: (a) that a given cell strain may be heterogeneous with respect to innate sensitivity ${ }^{8}$; (b) that cells may undergo marked fluctuations in radiation sensitivity during the division cycle ${ }^{9} ;(c)$ that inhomogeneities in degree of oxygenation might exist, particularly in a tumour cell population in situ ${ }^{10}$. It may be presumed, therefore, that one or more of the following has been pertinent in each study: (1) A particular population may be homogeneous with respect to inherent sensitivity, degree of oxygenation, and presence of protective agents or other modifiers of radiation response. (2) The overall sensitivity of cell populations heterogeneous with respect to radiation 